\title{
The Effect of Myrmecodia pendans Ethanol Extract on Inflamed Pulp: Study on Sprague Dawley Rats
}

\author{
Janti Sudiono, Meylisa Hardina \\ Department of Oral Pathology, Faculty of Dentistry, Universitas Trisakti, Jakarta, Indonesia
}

Background: Inflammation is a body response caused by injury and infection. Pulpitis is a pulp tissue inflammation which is the continuous process of pulp hyperemia by bacteria invasion. Myrmecodia pendans or Sarang semut is known to contain flavonoid compound which has the anti inflammation effect. The purpose of this study is to investigate the effect of Myrmecodia pendans ethanol extract on the healing process of pulp inflammation.

Materials and Methods: This experimental study involved pre- and post-in vivo treatment of 27 Sprague Dawley rats in which the inducted pulpitis model was obtained by injecting $0.01 \mathrm{~mL}$ Porphyromonas gingivalis into the dental pulp for 48 hours. Subjects were divided randomly into Group I (negative control), Group II (pulpitis treated by Myrmecodia pendans extract ethanol as treatment group), and Group III (pulpitis treated by $\mathrm{Ca}(\mathrm{OH})_{2}$ as positive control group). Group II and III as pulpitis treatment groups were divided into subgroups based on the induction periods of 48 hours ( 2 days), 168 hours ( 7 days), and 366 hours (14 days). All specimens were processed into the slides and evaluated microscopically for the healing process.

Results: The result of this study showed significant difference $(p<0.05)$ among groups on day 2,4 and 7 . On day 4 , the pulpitis treatment group of Myrmecodia pendans extract showed better healing process than $\mathrm{Ca}(\mathrm{OH})_{2}$. On day 7 , the pulpitis treatment group of $\mathrm{Ca}(\mathrm{OH})_{2}$ showed better healing process than Myrmecodia pendans extract. On day 14, both of the pulpitis treatment groups showed normal pulp.

Conclusion: Myrmecodia pendans ethanol extract is effective for the healing process of inflamed pulp.

Keywords: inflamed pulp, Myrmecodia pendans, sarang semut, $\mathrm{Ca}(\mathrm{OH})_{2}$, healing process

\section{Introduction}

Inflammation is a respond, normal protection of destroyed tissue due to physical, chemical injury or microbiology invasion. Inflammation is an effort of the body to activate the immune system or destroy the organism agent, clean the irritant and organize tissue repair. ${ }^{1}$ Inflammation is a local protective response toward tissue injury, to relieve or isolate the causative agent as well as destructed tissue itself. Inflammation is a complex reaction within vascular connective tissue towards exogenous or endogen stimuli. In simpler way, inflammation is a protective response to

Date of submission: March 4, 2019

Last Revised: April 22, 2019

Accepted for publication: April 25, 2019

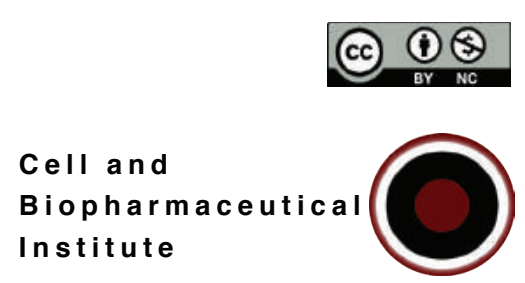

Corresponding Author:

Janti Sudiono

Department of Oral Pathology

Faculty of Dentistry, Universitas Trisakti

Jl. Kyai Tapa Grogol, Jakarta 11440, Indonesia

e-mail: jantish@trisakti.ac.id 
eliminate the causative agent as well as necrotic cells and tissue. Well-known inflammation signs are rubor, dolor, calor, tumor and functio laesa. Rubor caused by arterial vasodilation increases vascularization within the injured area. ${ }^{2}$ Final response of inflammation is the release of plasm protein and phagocyte into the damaged area in order to isolate, destroy or inhibit the invasion of these agents, and to clean the debris and prepare the tissue for wound healing process. $^{2}$ Without inflamed reaction, the cause of injury, such as bacteria, will disperse throughout the body or the injury could not heal.

Inflammation occurred within the pulp tissue called pulpitis might be due to physical or mechanical causative agent, bacteria and chemical toxic. Usually bacteria or its toxin come through caries process. Pulpitis is an inflamed pulp tooth usually following caries. ${ }^{3}$ Pulp tissue is located in the tooth bone (dentin) and therefore it will be difficult clinically to decide how far the inflamed process has been occurred. ${ }^{4}$ Pulpitis or inflamed pulp tooth can be acute or chronic, partially or complete and infectious or noninfectious. It occurs due to irritated pulp tissue by biologic or a-biologic injuries factor, such as toxin of bacteria or physical and chemical respectively. 3,4

There are a lot of plants which have been traditionally used to relieve swelling that could be used as an alternative of anti inflammation remedy. ${ }^{5}$ Myrmecodia pendans is one of epiphytes from Rubiaceae which can be associated with ant. This plant spreads across Malaysia, Philippine, Cambodia, Sumatera, Kalimantan, Jawa, Papua Nugini and Solomon. The varieties of this plant found in Papua islands with its specific local species located on the high land. ${ }^{6}$ Active compounds content of this plant are flavonoid, tannin, and polyphenol act as human body antioxidant. Myrmecodia pendans ethanol extract has anti inflammation potency. ${ }^{7}$

The analysis composition of phytochemical content revealed that flavonoid is able to inhibit accumulation of leucocyte, neutrophil degranulation, and inflammatory chemical mediator production such as histamine and prostaglandin as well as to neutralize reactive oxygen species (ROS). ${ }^{8}$ Other content material of Myrmecodia pendans are tocopherol, magnesium, calcium, ferrum, phosphor, natrium and zincum. ${ }^{8}$ Flavonoid act as anti inflammation, anti oxidant, anti microbial for human body. ${ }^{9}$ Flavonoid has role to protect cell structure, increase vitamin $\mathrm{C}$ activity, anti inflammation, osteoporosis prevention, and antibiotic. ${ }^{8}$ Flavonoid may directly act as antibiotic by disrupting the function of microorganism like bacteria and virus..$^{6,8,9}$

Traditional herbal medicine is an alternative treatment with minimal side effect. Indonesia is one country that has a lot of herbal traditional medicine. Some genus of Rubiaceae family, such as Myrmecodia was known to have pharmacology potency like flavonoid as anti inflammation. ${ }^{7}$ The previous in vitro study of Myrmecodia ethanol extract had shown the decrease of human oral tongue squamous cell carcinoma cell line (SP-C1). ${ }^{7}$ Another in vitro study showed that Myrmecodia extract was able to inhibit the squamous cell carcinoma proliferation through induction of the arrest of cancer cell cycle and apoptosis, and moreover the decrease of growth, invasion and metastasis of cancer cells. ${ }^{7}$ There was also an in vitro study that revealed the n-hexane fraction of Myrmecodia pendans inhibits cell survival and proliferation in colon cancer cell line. ${ }^{8}$ However, there is no in vivo study of Myrmecodia pendans. Therefore this study aims to analyze the influence of anti inflammation content of Myrmecodia pendans ethanol extract by evaluating the microscopic feature changes within pulpitis of molar tooth rats which induced by Porphyromonas gingivalis.

\section{Materials and methods}

This study was approved by Animal Care and Use Committee (ACUC) Veterinary Teaching Hospital, Animal Medical Faculty, Bogor Agricultural University (No.352016 ACUC RSHP FKH-IPB).

\section{Subjects}

Subjects used in this study was Sprague Dawley rats $(n=30)$. Subjects was randomly divided into negative control, pulpitis group, pulpitis treatment group with Myrmecodia pendans ethanol extract, pulpitis treatment group with $\mathrm{Ca}(\mathrm{OH})_{2}$ as positive control. The pulpitis treatment groups were divided into $48 \mathrm{~h}$ (day 2), $168 \mathrm{~h}$ (day 7), and $336 \mathrm{~h}$ (day 14) sub groups.

All subjects were intra muscularly anesthetized with ketamine (Ketalar ${ }^{\circledR}$, Warner Lambertvb v, Irlandia) (70 mg/ gram body weight) and xylazine $\mathrm{HCl}$ (Rompun ${ }^{\circledR}$, Bayer, Leverkusen, Germany) (8-12 $\mathrm{mg} /$ gram body weight) in sterile phosphate buffered saline (PBS) before treatment. Occlusal surface of molar tooth was opened up to the pulp roof by diamond round bur (diameter $0.10 \mathrm{~mm}$ ). Then Porphyromonas gingivalis $\left(3 \times 10^{8}\right.$ colony-forming unit $(\mathrm{CFU}) / 25 \mathrm{~mL})$ as much as $0.01 \mathrm{~mL}\left(12 \times 10^{4}\right.$ bacteriae $)$ was 
dropped into the pulp chamber used tuberculin syringe, and closed with Glass ionomer cement (GIC) Fuji IX (GC America, Illinois, USA) temporary filling.

\section{Myrmecodia pendans Ethanol Extract}

Myrmecodia pendans ethanol extract was prepared at Laboratorium Balai Penelitian Tanaman Obat dan Rempah (Balitro), Bogor, Indonesia. First, the simplisia was macerated within $70 \%$ ethanol solution with the ratio $1: 5$, then simplisia and $70 \%$ ethanol were mixed for $3 \mathrm{~h}$ and saturated for $24 \mathrm{~h}$ resulted in residue and filtrate I. About $70 \%$ ethanol was added into the residue and mixed for $1 \mathrm{~h}$ and used paper filter to get residue and filtrate II. After the filtrate I and II evaporated, the crude extract were collected.

\section{Preparation of Porphyromonas gingivalis}

Porphyromonas gingivalis used was Porphyromonas gingivalis ATCC 3327 from MiCoRE Laboratory, Universitas Trisakti, Jakarta. About 3.7 gr of brain heart infusion (BHI) broth was dissolved into $100 \mathrm{~mL}$ aquadest and put into autoclave $121^{\circ} \mathrm{C}$ for 15 minutes. After the temperature decreased into $60^{\circ} \mathrm{C}, 5 \mathrm{~mL}$ of BHI broth was put into the tube. Then $100 \mu \mathrm{L}$ of Porphyromonas gingivalis was pippetted into tube and was put into $37^{\circ} \mathrm{C}$ incubator for 3 days. Lastly, the optical density (OD) was checked.

\section{The Specimen Preparation for Microscopic Evaluation}

The specimen of teeth within jaw resection were processed through fixation using 10\% buffered formalin for $24 \mathrm{~h}$ and decalcification using $10 \%$ formic acid for $48 \mathrm{~h}$ at Laboratory of Anatomic Pathology, Dharmais Cancer Hospital and the scoring was done at Department of Oral Pathology, Faculty of Dentristry, Unversitas Trisakti.

All specimens were processed into the slides and evaluated microscopically for the healing process. Score 1 showed that normal pulp with presence of odontoblast cells, normal blood vessel and mild inflammatory cells, score 2 showed that blood vessels and inflammatory cells dominated within pulp tissue, meanwhile score 3 showed that necrosis or fibrosis dominant within pulp tissue.

\section{Results}

Negative control group showed normal pulp that odontoblast cells line the pulp chamber and the normal blood vessels (Figure 1A) while on day 2 of inflamed pulp (pulpitis), there is increase of blood vessels that look dilatation with the inflammatory cells disperse out of the vessels (Figure 1B).

On day 4, after getting treatment for 2 days with extract of Myrmecodia pendans, the condition of pulpitis has not been recovery yet where there is still increase of inflammatory cells and blood vessel dominated as normal responds of pulp tissue toward inflammation (Figure 2A). This condition looks better than those of pulpitis treated by $\mathrm{Ca}(\mathrm{OH})_{2}$ whereas the fibrosis occurred replaced the destroyed cells (Figure 2B).

On day 7 , the condition of pulpitis treated by extract of Myrmecodia pendans showed same condition as those on day 4. There is still the figure of inflammation showed by
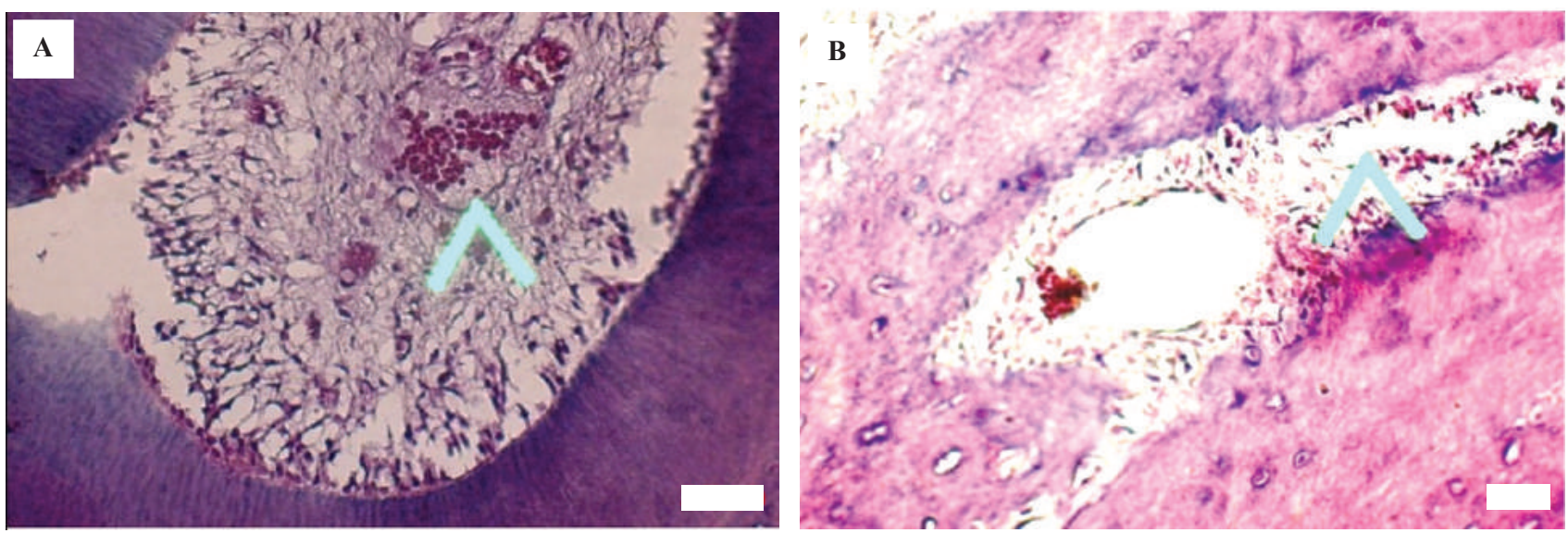

Figure 1. Negative control group and pulpitis group on day 2. A: Normal pulp showed the presence of odontoblast cells and normal blood vessel (arrow, score 1). B: Pulpitis group showed increase of inflammatory cells and blood vessels dominated (arrow, score 2). White bar: $20 \mu \mathrm{m}$. 

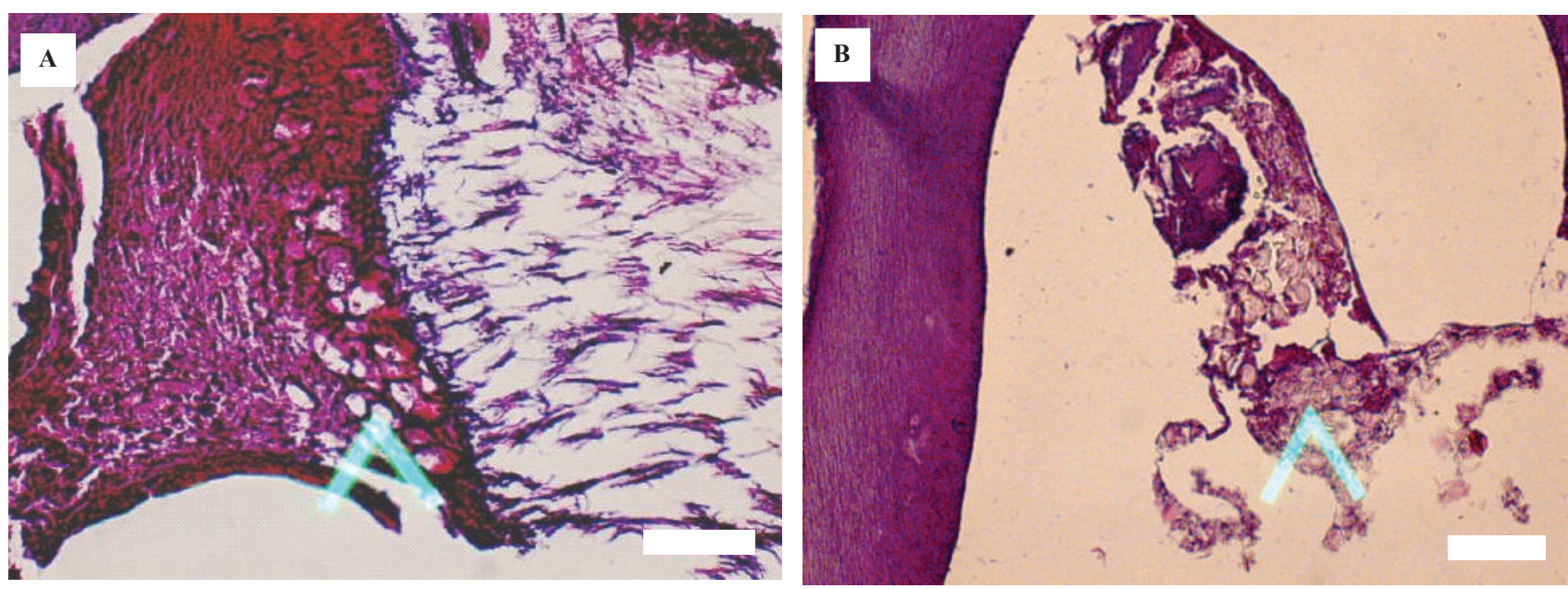

Figure 2. Treatment groups on day 4. A: Treatment group with Myrmecodia pendans extract, showed increase of inflammatory cells and blood vessel dominated (arrow, score 2). B: Treatment group with $\mathrm{Ca}(\mathrm{OH})_{2}$ /positive control showed fibrosis (arrow, score 3). White bar: $20 \mu \mathrm{m}$.

increase of blood vessels (Figure 3A) different from those of treated by $\mathrm{Ca}(\mathrm{OH})_{2}$ that showed the features of normal pulp (Figure 3B). On day 14, both treatment groups of Myrmecodia pendans and $\mathrm{Ca}(\mathrm{OH})_{2}$, showed accomplished recovery as normal pulp with odontoblast cells lining and normal vascular supply as shown on Figure 4A and 4B respectively.

The distribution of sample scores were shown on Table 1. Kruskal Wallis test showed significant difference among groups with $p=0.00<0.05$ among groups. On day $4(96 \mathrm{~h})$, there was significant difference $(p=0.00<0.05)$ between treatment groups whereas the treatment group with Myrmecodia pendans extract showed more healing process than those of $\mathrm{Ca}(\mathrm{OH})_{2}$ group. On day $7(168 \mathrm{~h})$ the $\mathrm{Ca}(\mathrm{OH})_{2}$ group showed better result in pulpitis healing process than those of Myrmecodia pendans extract with significant difference $(p=0.00<0.05)$. On day $14(336 \mathrm{~h})$, both the treatment groups showed normal pulp.

\section{Discussion}

The histopathological features of pulpitis showed increase inflammatory cells and vascular supply as normal inflammatory respond of pulp tissue toward stimulating agent as shown on day $2(48 \mathrm{~h})$ and day $4(96 \mathrm{~h})$. The stimulating agent in this study is from biological etiology
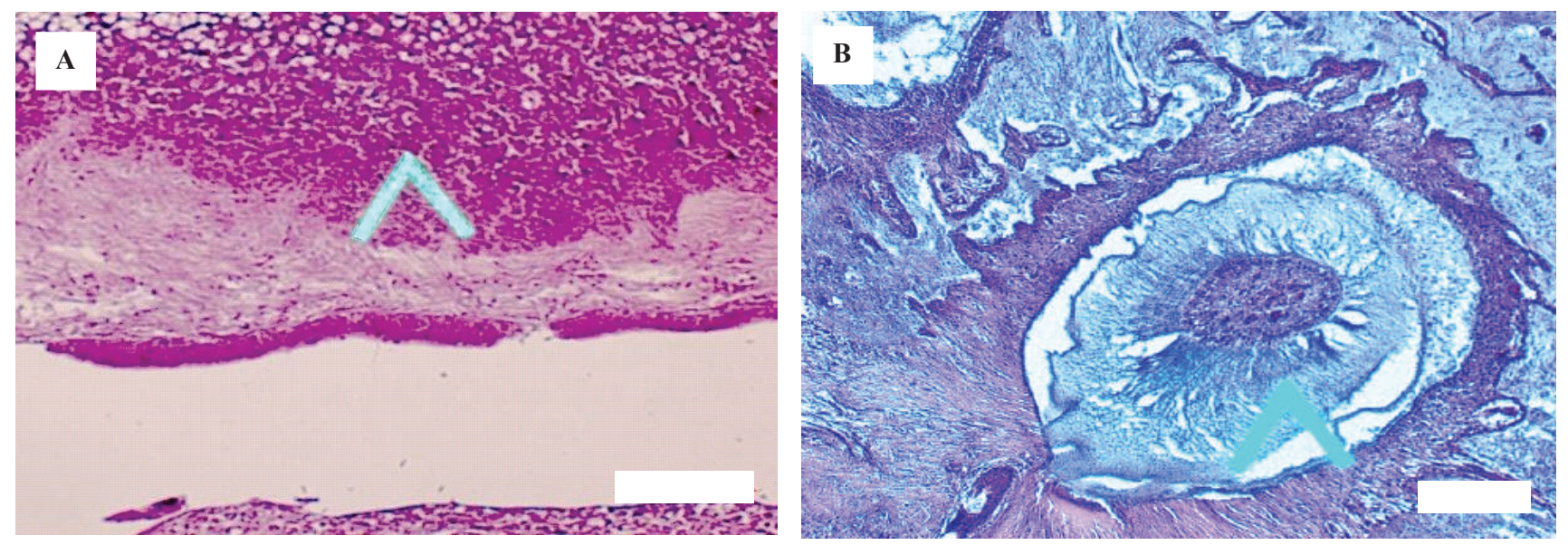

Figure 3. Treatment groups on day 7. A: Treatment group with Myrmecodia pendans extract showed increase blood vessel (arrow, score 2). B: Treatment group with $\mathrm{Ca}(\mathrm{OH})_{2} /$ positive control showed normal pulp (arrow, score 1). White bar: $20 \mu \mathrm{m}$. 

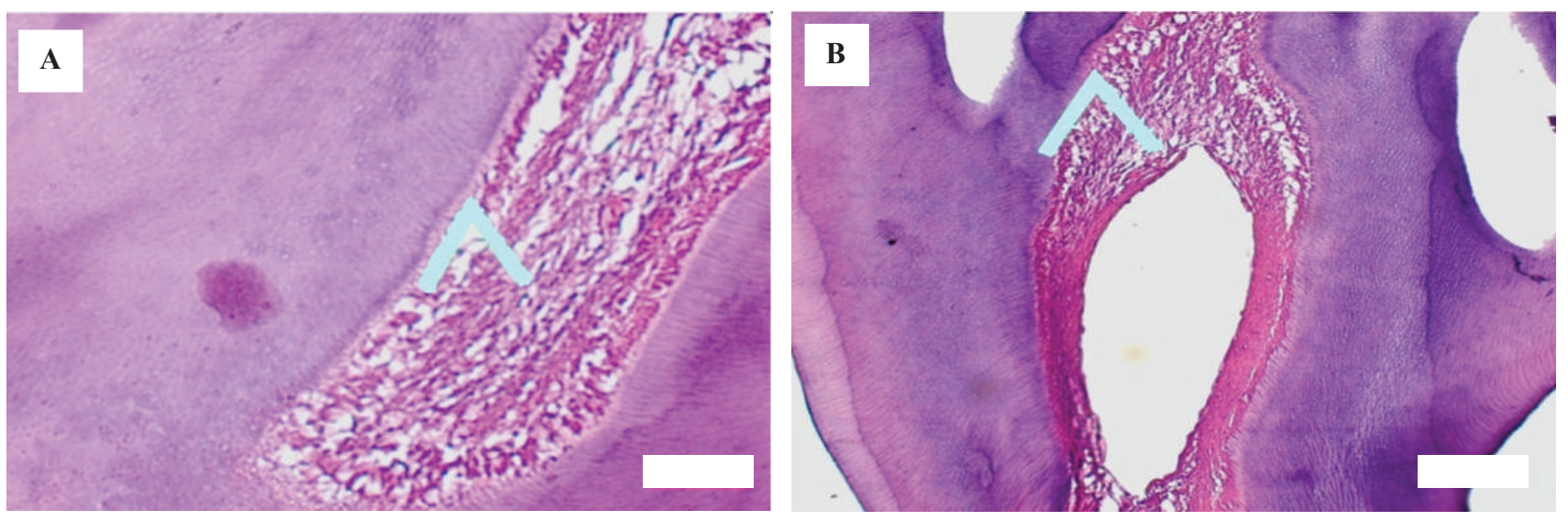

Figure 4. Treatment groups on day 14. A: Treatment group with Myrmecodia pendans extract showed odontoblast cell, normal bood vessel and mild inflammatory cells (arrow, score 1). B: Treatment group with $\mathrm{Ca}(\mathrm{OH})_{2} /$ positive control showed odontoblast cells, normal blood vessel and mild inflammatory cells (arrow, score 1). White bar: $20 \mu \mathrm{m}$.

factor of Porphyromonas gingivalis with its toxin that penetrated into the pulp chamber. This assumed that Porphyromonas gingivalis has a lot of virulent factors like fimbriae, haemagglutinin, capsule, outer vesicle membrane, strong hydrolytic enzyme, lipo-polysaccharide complex (LPS). This virulent factor is able to do maintenance mechanism resulted in tissue destruction. Studies reveal that any irritant within enamel even in small intention is able to mobilize inflammatory cells into pulp tissue. ${ }^{9}$

The Myrmecodia pendans extract as herbal remedies used in this study showed the role of its phytochemical content such as flavonoid. Flavonoid may role directly as antibiotic by disturbing the microorganism or viral function ${ }^{7}$ and as antioxidant against free radical. ${ }^{10}$ Such phenolic compound is a potent antimicrobial agent ${ }^{11}$ that could be extracted by several methods. Heat reflux is a common method for the extraction of bioactive compounds from natural products ${ }^{7}$ as had been done in this study and also already proved in this study, based on the result on day 4 (96 h), whereas the treatment group with Myrmecodia pendans extract showed better condition of healing process than those of $\mathrm{Ca}(\mathrm{OH})_{2}$ group and significant differences statistically. This is due to flavonoid inhibits leukocyte accumulation, neutrophil degranulation and inflammatory mediator releasing. Flavonoid acts as antioxidant and anti microbe beside its anti inflammation property. ${ }^{9}$ Flavonoid may protect cell structure and as antibiotic, flavonoid disrupts microorganism function. ${ }^{79}$ This result also supported the study that Myrmecodia pendans ethanol $70 \%$ dried extract showed no toxic on fibroblast using
3-(4,5-Dimethylthiazol-2-yl)-2,5-diphenyltetrazolium bromide (MTT) assay method. The higher concentration of extract showed the increase in viable cells and the decrease in inhibition percentage of cells proliferation and does not show any toxic effect on normal cells. ${ }^{7}$

The control positive used in this study is the commercial product medicament of pulp capping on pulpitis condition that is $\mathrm{Ca}(\mathrm{OH})_{2} \cdot \mathrm{Ca}(\mathrm{OH})_{2}$ is one of the developed materials due to its ability to form dentinal bridge. Several efforts have been done to find out material that can potentially increase barrier hard tissue formation on exposed pulp tooth. ${ }^{12} \mathrm{Up}$ to now, $\mathrm{Ca}(\mathrm{OH})_{2}$ has been used as standard material for pulp capping procedure due to its clinical high rate successful cases. ${ }^{13}$ The result of this study supported those basic scientific reason that direct pulp capping may act by increasing peritubular dentin and tertiary dentin formation response to microorganism stimulant. It is proved especially on day $7(168 \mathrm{~h})$ that the $\mathrm{Ca}(\mathrm{OH})_{2}$, showed better condition in pulpitis healing process than Myrmecodia pendans extract.

The pulpitis has been recovery yet on day 14 (336 h) both in Myrmecodia pendans extract and $\mathrm{Ca}(\mathrm{OH})_{2}$ pulpitis treatment groups. This result proved that Myrmecodia pendans has anti inflammation effect therefore could be used as direct pulp capping method due to its equal potency to those of the commercial direct pulp capping $\mathrm{Ca}(\mathrm{OH})_{2}$.

\section{Conclusion}

Myrmecodia pendans ethanol extract exhibits anti inflammation effect that decreases inflammatory cells and 
Table 1. The distribution of score among samples.

\begin{tabular}{|c|c|c|c|c|c|c|c|c|}
\hline \multirow{3}{*}{$\begin{array}{l}\text { Sample } \\
\text { Number }\end{array}$} & \multirow{3}{*}{$\begin{array}{c}\text { Negative } \\
\text { Control } \\
\text { (Normal } \\
\text { Pulp) }\end{array}$} & \multicolumn{7}{|c|}{ Pulpitis (Porphyromonasgingivalis Induction) } \\
\hline & & \multirow{2}{*}{$\begin{array}{l}48 \text { Hours } \\
\text { / Pulpitis } \\
\text { Group }\end{array}$} & \multicolumn{3}{|c|}{$\begin{array}{c}\text { Treatment Group with } \\
\mathrm{Ca}(\mathrm{OH})_{2} / \text { Positive Control }\end{array}$} & \multicolumn{3}{|c|}{$\begin{array}{l}\text { Treatment Group with } \\
\text { Myrmecodia pendans extract }\end{array}$} \\
\hline & & & Day4 & Day 7 & Day 14 & Day 4 & Day 7 & Day 14 \\
\hline 1 & 1 & - & - & - & - & - & - & - \\
\hline 2 & 1 & - & - & - & - & - & - & - \\
\hline 3 & 1 & - & - & - & - & - & - & - \\
\hline 4 & - & 2 & - & - & - & - & - & - \\
\hline 5 & - & 2 & - & - & - & - & - & - \\
\hline 6 & - & 2 & - & - & - & - & - & - \\
\hline 7 & - & 2 & - & - & - & - & - & - \\
\hline 8 & - & 2 & - & - & - & - & - & - \\
\hline 9 & - & 2 & - & - & - & - & - & - \\
\hline 10 & - & - & 2 & - & - & - & - & - \\
\hline 11 & - & - & 3 & - & - & - & - & - \\
\hline 12 & - & - & 3 & - & - & - & - & - \\
\hline 13 & - & - & - & 1 & - & - & - & - \\
\hline 14 & - & - & - & 2 & - & - & - & - \\
\hline 15 & - & - & - & 1 & - & - & - & - \\
\hline 16 & - & - & - & - & 1 & - & - & - \\
\hline 17 & - & - & - & - & 1 & - & - & - \\
\hline 18 & - & - & - & - & 1 & - & - & - \\
\hline 19 & - & - & - & - & - & 2 & - & - \\
\hline 20 & - & - & - & - & - & 2 & - & - \\
\hline 21 & - & - & - & - & - & 3 & - & - \\
\hline 22 & - & - & - & - & - & - & 2 & - \\
\hline 23 & - & - & - & - & - & - & 2 & - \\
\hline 24 & - & - & - & - & - & - & 2 & - \\
\hline 25 & - & - & - & - & - & - & - & 1 \\
\hline 26 & - & - & - & - & - & - & - & 1 \\
\hline 27 & - & - & - & - & - & - & - & 1 \\
\hline
\end{tabular}

recovers blood vessels within pulpitis therefore effective for the healing process of pulpitis. This anti inflammation effect is equal to those of pulpitis commercial medicament $\mathrm{Ca}(\mathrm{OH})_{2}$ especially on day 14 .

\section{References}

1. Mycek MJ, Harvey RA, Champe PC, Fisher BD. Pharmacology. 2nd ed. Jakarta: WidyaMedika; 2001.

2. Corwin EJ. Handbook of Pathophysiology. 3th ed. Philadelphia: Lippincort Williams \&Walkins; 2008.
3. Kim S, Trowbridge HO. Pulp reaction to caries and dental procedures. In: Cohen S, Burns RC, editors. Pathway of The Pulp. 3rd ed. London: CV Mosby Co; 2000. p.5-20.

4. Cohen S. Diagnostic procedures. In: Cohen S, Burns RC, editors. Pathway of The Pulp. 3rd ed. London: CV Mosby Co; 2000. p. 21-35.

5. Uzcategui B, Avila D, Roca HS, Quintero L, Ortega J, Gonzalez B. Anti-inflammatory, antinociceptive, and antipyretic effects of Lantana trifolia Linnaeus in experimental animals. Invest Clin. 2004; 45(4): 317-22.

6. Subroto A, Saputro H. Destroyed Disease by Sarang Semut. Jakarta: Penebar Swadaya; 2009. 
7. Sudiono J, Tri Oka C, Trisfilha P. The Scientific base of Myrmecodia pendans as herbal remedies. Br J Med Med Res. 2015; 8(3): 230-7.

8. Bashari MH, Hidayat S, Ruswandi YAR, Putri T, Qomarilla N, Dwiwina RG, et al. The n-hexane fraction of Myrmecodia pendans inhibits cell survival and proliferation in colon cancer cell line. Int J Pharm Pharm Sci. 2018; 10(1): 108-12.

9. Lakhanpal P, Rai D. Quercetin a versatile flavonoid. Int J Med Update. 2007; 2(2): 20-35.

10. Ilavarasan R, Mallika M, Venkataraman S. Anti inflammatory and antioxidant activities of cassia fistula bark extracts. Afr J Tradit Complement Altern Med. 2005; 2(1); 70-85.

11. Manna PM, Sinha PC. Protective role of arjunolic acid in response to streptozotocin induced type-i diabetes via mitochondrial dependent and independent pathways. Toxicology. 2009; 257(1-2): 53-56.

12. Iwamoto $\mathrm{CE}$, Adachi E, Pameijer $\mathrm{CH}$, Barnes D, Romberg EE, Jefferies S. Clinical and histological evaluation of white ProRoot MTA in direct pulp capping. Am J Dent. 2006; 19(2): 85-90.

13. Fernandes AM, Silva GA, Lopes NJr, Napimoga MH, Benatti BB, Alves JB. Direct capping of human pulps with a dentin bonding system and calcium hydroxide: An immunohistochemical analysis. Oral Surg Oral Med Oral Pathol Oral Radiol. 2008; 105(3): 385-90. 